\title{
Individual, interpersonal and economic challenges of underemployment in the wake of COVID-19
}

\author{
Manjeet Kaur*, Pratibha Goyal and Mini Goyal \\ Punjab Agricultural University, Ludhiana, Punjab, India
}

Received 1 June 2020

Accepted 15 July 2020

\begin{abstract}
.
BACKGROUND: COVID-19 has caused economic slowdown all across the globe. It results in job loss on the one hand and less wages, increased working hours, overqualified employees and part time jobs on the other hand. Low demand of labour and a huge availability of work force will put many in a disadvantageous position, where they will have to compromise with the circumstances by being underemployed. Cabinet decisions, by some Indian states like Uttar Pradesh, to suspend the labour laws related to minimum wage, bonus, working hours and other employee benefits will put workers in a highly disadvantageous position of being underemployed. This may lead to many socio-economic, psychological and health-related implications.
\end{abstract}

OBJECTIVE: The aim of this paper is to provide a comprehensive review on the concept of underemployment, its types and consequences.

METHODOLOGY: A critical and constructive analysis of the literature was performed.

RESULTS: The findings reveal that if employment does not provide workers with proper opportunities to use their education, time, skills and expertise, it can create stressful situations in workers' lives.

CONCLUSION: The problem needs both a diagnosis and robust treatment in order to have better outcomes at the individual, organisational and national levels.

Keywords: Inadequate employment, unemployment, underemployment, slowdown, labour, stress, COVID-19

\section{Introduction}

In the wake of the COVID-19 pandemic, lockdown has been declared all across the world. Economic activity is at a standstill and millions of jobs are being lost. Underemployment is expected to increase at large scale as there could be more part time employment or long working hours at reduced wages. Globally working hours may decline by 6.7 percent

*Address for correspondence: Manjeet Kaur, Research Scholar, H. no 14 Phase 3, Khanna Colony, Threeke Road, Ludhiana, Punjab 142028, India. Tel.: +91 7589194045; E-mail: kaurmanjeet 2694@gmail.com. from the full time 48 hour working week, in the second quarter of 2020, affecting 195 million full time workers. Most of the people will face loss of income even if they find some work [1]. Because of the shutdown of majority of industries, the current underemployment rate in Australia is 9.1 percent and can increase up to $15 \%$ in coming months [2]. In Hong Kong, between January to March, the unemployment rate increased from 3.7 percent to 4.2 percent and underemployment rate jumped from 1.5 percent to 2.1 percent [3]. Of the 2.5 lakh guest workers seeking a green card in the US, about 2 of them on $\mathrm{H}-1 \mathrm{~B}$ visas could lose their legal status by the end of June 2020 
[4]. As per the report of Centre for Monitoring Indian Economy (CMIE) in India, urban unemployment rate climbed to 30.9 percent and overall unemployment rate rose to 23.4 percent because of the impact of COVID-19 on the economy. It was roughly estimated that in just two weeks of lockdown, 50 million people lost jobs in India [5]. Similarly, in Canada the shutdown of the economy due to COVID-19- came as a shock for the Canadian labour market as more than $1 / 3$ of their potential labour force did not work at all or worked for less than half of their usual hours in the month of April [6].

Employment is an important part of life as it provides a means to earn a living, improve the standard of living and social status, a sense of self confidence and self-respect. Unemployment is a total lack of work but the underemployed workers involuntarily engage in low paid jobs or work less than usual hours or get those employments which are not appropriate or productive. They have to settle for those lower level jobs for which they are overqualified. Despite being capable of working full time, they have to work part time and are paid lower wages. Underemployment is a big problem because even though people are employed, they are not able to work as per their capabilities and capacities.

Even before the pandemic, large numbers of people, both in rural and urban areas did not have access to decent work as they were working below their ability [7]. In India, due to privatisation driven shrinkage of government jobs, poor quality technical and management education institutes producing less employable human resource and technology driven downsizing of organisations, underemployment was stark. Instead of white-collar jobs, opportunities were more in lower level jobs like delivery boys, security guards, sales and marketing. The reports of B.Tech., MBA and Ph.D. candidates applying for peon's position have been common. In the postCOVID-19 period, the situation is likely to be more difficult, as large-scale retrenchments may be done by both domestic and international employers. Low demand of labour and a huge availability of work force will put many in a disadvantageous position, where they will have to compromise with the circumstances by being underemployed. It is generally predicted that after losing their employment, when people are re-employed, their new jobs are of low quality as compared to the ones they lost [8]. This puts them at the risk of underemployment. In order to earn their living people are forced to work at inferior jobs in terms of hours, income, qualifications or skills. Uttar Pradesh, one of the most populous states in India, has already passed an ordinance that has suspended 35 out of 38 labour laws in the state for the next three years. Besides suspending several labour rights, this step increases working time from eight hours to twelve hours a day and scraps the minimum wage provision. The rationale behind this is told to be an attempt "to bring economy back on the track" which has been hit hard by the lockdown [9].

Though unemployment is a key indicator in measuring the health of the economy yet in COVID-19 scenario, it is equally important to measure underemployment as well [2]. In the coming times, it is predicted that most of the people are going to lose their jobs. Even if they get some work, the job may not be the same kind as they were doing before. In order to survive and to fulfil the needs of their family, they may be compelled to accept underemployment. Therefore, the study of unemployment alone is not sufficient for understanding the shortcomings of labour market. Besides unemployment, it becomes important for countries to measure underemployment also for analysing labour market efficiencies as the world braces for the post-COVID-19 environment.

In this light an attempt was made to study the concept, forms and consequences of underemployment.

\section{Underemployment}

Underemployment is a low-quality employment situation where employees are undervalued and underutilized [10-14]. It is related to the inadequacy in work opportunities which can be in terms of hours, income, rank or use of expertise $[15,16]$. The underemployed workers are engaged in jobs which are substandard as compared to their goals and expectations [17].

This depicts the ill-defined situation between employment and unemployment [18]. Distinguishing between the two, it was identified that unemployment is an all-or-nothing condition whereas underemployment has an array of objective and subjective factors that are crucial in defining it [19]. The objective factors of underemployment include number of hours worked, a worker's salary and a match between employee's expertise and his or her job [20], while subjective factors include perception of employees that they are overqualified for their present job and urge to use their work expertise remains unfulfilled [21]. 
Underemployment has, sometimes, been defined very narrowly to account for part time employment only [16]. This is also referred to as visible underemployment or time-related underemployment, in which an employee works fewer hours compared to the normal working hours determined for the job. The broader perspective includes several other inadequate or invisible employment situations which prevent worker's full potential from being realized i.e. insufficient use of skills and experience [14], over education, employment outside one's area of enquiry, overqualification for the present position and income significantly lower than which was paid in the previous job [17]. It includes all the persons who want to shift from their current job to another one and those who want to modify their activities through improving the quality of equipment they use, reorganizing their work etc. in their self-employed or paid jobs. Various reasons of inadequate employment situations include insufficient use of worker's occupational skills, inadequate income in current job, inadequate tools, inconvenient work schedules, inadequate training for assigned tasks and excessive hours of work. So, the main forms of underemployment are time-related underemployment, income-related underemployment and overqualification. These are measured by different countries in different ways.

\subsection{Time-related underemployment}

Time-related underemployment is a situation in which an employee works less hours than the predetermined threshold and wants to work additional hours and is available to do so. It does not include those who are working part time by their own wish $[15,22]$. Threshold time for time-related underemployment varies from country to country. In the USA, Australia and Indonesia it is involuntary part time employment for less than 35 hours per week [23-25], while in Turkey it is reported as less than 40 hours [26]. The threshold of $30 \mathrm{hrs}$ per week was taken for defining time-related underemployment in Malaysia [27]. This threshold is decided on the basis of average, median or mode values of working hours or it can be decided on the basis of rules for hours of work specified in relevant legislation or labour practices in the countries [15].

\subsection{Income-related underemployment}

With regards to income-related underemployment, the worker perceives that he is underpaid as compared to his previous employment or is paid less compared to people with similar knowledge, skills, abilities and other characteristics [11]. In order to determine income-related underemployment, normative weekly wage was determined by different authors. The normative weekly wage for urban people under the age of 65 , was 1.25 times the poverty threshold and those whose weekly earnings were lower than the normative weekly wage were classified as income underemployed [28-30]. The same standard is followed by the Social Security Administration of USA [31]. The more objective definition for low wage employment was developed by adding the condition that the worker must have worked for at least 45-50 weeks during the past year and his earning is less than 1.25 times the official poverty [32].

It was concluded that in order to measure underpayment, employees would be asked how much they earn in their present employment as compared to previous one and how they feel they are being paid in relation to people in similar positions [33]. Incomebased underemployment exists when the worker's income is less than what he expects and seeks to change his current work situation in order to increase his income [23]. It was revealed that income-related underemployment is highest in agricultural and informal sectors, especially in case of women [34].

\subsection{Overqualification}

Overqualification is a condition of education and occupation mismatch and misallocation of resources [35]. Over education and skill-related underemployments are sometimes considered to be the same. But the researchers are of the view that estimation of education-based underemployment alone is not sufficient because it tends to ignore skills that are acquired through training or on-the-job experience [36]. Skill-based underemployment occurs when workers' training and skills are not utilized in their current occupation [23, 37, 38]. Even a highly skilled and well-paid employee can be skill-related underemployed if his expertise, skills, abilities and knowledge are not put to good use [39]. It will include all the persons who during the short reference period want to change their current employment situation and are available to do so in order to properly utilize their occupational skills. In case of overqualification, which may be education- or skill-based, the results obtained by the workers are not the maximum that can be achieved when there is a right person at the right job. 
A still broader view of qualification-based underemployment was taken, where a worker is considered overqualified not only in terms of education or skills but also knowledge, capabilities, work experience, and competencies exceed the required level for the job [40]. A more holistic view was also given by defining the following dimensions of overqualification:

a) Talent use gap - The situation in which people are not able to access education because of its high costs and discrimination done on the basis of race, gender or other characteristics. Many intelligent and talented people may remain at lower level jobs because of lack of formal education.

b) Credential gap - This occurs when the there is a mismatch between the formal education attained by a person and education that is required for the entry in job.

c) Performance gap - This reflects the situation when there is a mismatch between the education acquired and education that is actually needed to perform the work.

d) Knowledge gap - This occurs when the knowledge, skills, abilities or expertise of people that are attained through their job experience are more than that is required for a specific job.

e) Relevance gap - When a person with advanced degrees finds that his education is not related to the content of the job, the relevance gap occurs. In this situation a dentist may be working as a clerk.

f) Subjective gap - This gap is based on the subjective perceptions of the workers. It occurs when a person feels that there is a mismatch between his/her qualification and the job requirements [41].

But the issue arises how to measure the gaps and quantify underemployment. The four main approaches to measure over education were defined as follows:

- Realized matches - Determining the difference between the education level and mean level of education of all workers in the same occupation group.

- Job analysis - Comparing the educational requirements determined by a job analyst for an occupation with the education attained by the worker.

- Indirect self-assessment-Perception of employees regarding the minimum level of education required for the job and the actual level of his education.

- Direct self-report - Directly questioning the workers whether they think they are over educated or not $[42,43]$.

It was revealed that if the educational attainment of worker is at least one standard deviation higher than the mean education requirement within his/her occupation then there will be an education mismatch [44]. Similarly, it can be applied to other parameters of overqualification.

\section{Underemployment and its hidden costs}

Underemployment has many hidden costs which are usually not calculated. It is harmful not only for individual who is experiencing that situation but also for the family, friends, organisation and economy at large. Thus, it can be a great cause of stress among people living in the society. Good employment is joyful event in one's life but loss of employment or inadequate employment makes the situation difficult [39]. It affects not only mental health and lifestyle but social life as well [45].

\subsection{Underemployment and the individual}

Health of a person is associated with the status of his/her employment. Jobs which provide better opportunities to workers to use their expertise are considered to be mentally healthier than those which do not provide such opportunities [46]. It adversely affects psychological wellbeing of individuals as researchers have found a positive relationship between underemployment and psychosocial stress, annoyance, depression, unfriendliness and insecurities. It was found that full time workers had lower stress levels and depressive symptoms while unemployed or part time workers had more stress, unhealthy eating habits and consumption of cigarette and alcohol [47]. Some authors observed that underemployed people, in short run, had an increased risk of depression, stress and lower self -esteem and in long run it affected their relationships with family, friends and employees [48, 49]. The effect of number of hours worked and strength of job identity on workers' job satisfaction, work-related stress, workrelated depression and overall life satisfaction was observed [50]. They found that at a given level of hours worked, stronger work identity was related to 
increased wellbeing of workers. Women who were working for long hours and had stronger work identity experienced less job-related stress but when work identity was weak, they experienced more job-related stress and depression.

\subsection{Underemployment and interpersonal relationships}

Underemployment can also affect the relationship of persons with his/her family, friends and even the organisation in which he/she is working. It was found that underemployment can affect relationship with spouse/partner, children, and friends and hence affects family and friendship networks. It can also lead to high turnover among employees, low standard of living, poor social status and greater marital discord [17]. Inadequate employment situations like long hours of work harm the relationships in home specifically marital relationship and child development because it reduces the time spent with their partner and children which is very important for the quality of life [51]. The work schedules of not only mothers but also fathers affect the wellbeing of children as well. Nonstandard work time had negative outcomes for parents and children. Parents working in nonstandard work schedules noted worse functioning of family, increased depressive symptoms and poor parenting and their children experienced social and emotional problems [52]. Children, whose fathers were underemployed and had poor financial position, had less interaction with them [53]. It was also analysed that when children watched their parents struggling in their employment conditions it had a lasting impression on children and they did not see a need of higher education [54]. The quality of relationships was negatively impacted by the long hours of work and work overload [55]. Divorce was more common among couples when a husband is underemployed. Financial stress was also found to be responsible for the increased divorce risk [56]. It was also noted that those who are working in nonstandard work can suffer low income because of less or intermittent hours which can lead to great family and personal stress [57]. So, in addition to the adverse effect on individual's well-being, the stress resulting from underemployment can also result in negative impact on interpersonal relations.

Similarly, underemployment can also affect employee's relationship with his organisation. It may generate the feeling of social isolation and withdrawal among people [58]. A worker may feel left out of the loop among people because they may be missing out of work events or major interactions [59]. It may reduce the job satisfaction, organisational commitment and customer service [60]. Part time employees are generally low performers than permanent full time employees [61]. Underemployment in the form of over education was found to be negatively associated with the job involvement, job satisfaction, relationships with peers, and feelings of control and future aspirations [62]. It was found that overqualification was negatively related the affective commitment but had no relationship with normative or continuance commitment [63]. The characteristics of the job and its effect on job satisfaction was analysed and results revealed that job dissatisfaction will induce employees to search for new job and this effect is more persistent in case of young workers, workers working in private sector and workers with lower term [64]. Thus, if employees are not able to enjoy their work, they will feel frustrated and will contribute less to their personal and organisational goals.

\subsection{Underemployment and the economy}

Underemployment is bad for the economy as well. There is a view that it is a pervasive problem that affects not only individuals but the whole economy. It can lead to job insecurity, increased casualisation, and lower savings and from economy point of view it is a signal of inefficiency in labour utilization [65]. It was reported that inadequate underemployment can reduce the growth potential of the economy and also put a question on how society is using its human capital [66]. Underemployment at macroeconomic level can lead to labour underutilization, inequalities in income, loss of productive jobs and output, reduced consumer demand, increased poverty, lower competitiveness and slowdown of economic growth [65]. So, it can be concluded that underemployment is harmful for the health of the economy.

Underemployment can crucially affect the citizenship behaviour of individuals and can lead to more property crimes, lower involvement in social services, lower participation in voting and loss of desire to promote welfare of others [17]. It was analysed that underemployment can lead to lower political participation and increased rate of crimes. When these two outcomes are combined with the economic, interpersonal relations and psychological stress caused by underemployment, it can drain the community's resources [54]. It can be concluded that effects of underemployment are similar to those 
of unemployment. If underemployment continues to persist, it could even cause civil unrest and violence. Thus, if employees work in a job that does not meet their needs and expectations it can result in a negative effect on their physical and psychological health.

\section{Conclusion}

Underemployment puts a worker in a disadvantageous position as he works for increased hours, reduced salary, underutilises his skills and expertise or gets jobs which are not appropriate or productive. The current economic slowdown and relaxation in some important laws which were the result of the century's old struggle of workers for their rights will make large number of workers underemployed. Despite being employed, many will not be able to work as per their capabilities and capacities. This may lead to adverse socio-economic, psychological and health effects. Therefore, it is important to determine the interventions that may help to reduce these negative outcomes. While unemployment is nakedly and unashamedly visible as a sign of an unhealthy economy, underemployment, on the other hand, is like a latent and passive manifestation. One may not see it or be able to assess it but it is an underlying malaise that needs both a diagnosis and a robust treatment both at microeconomic and macroeconomic level.

\section{Acknowledgments}

This study was completed as a component of a Philosophy Doctorate (PH.D.) on stress among underemployed executives in agro-based industries in Punjab, Punjab Agricultural University, Ludhiana, India.

\section{Conflict of interest}

None to report.

\section{References}

[1] ILO. ILO Monitor: COVID-19 and the world of work. Second edition. [updated $2020 \mathrm{Apr} 7$; cited $2020 \mathrm{Apr}$ 2020]. Available from https://www.ilo.org/wcmsp5/groups/ public/@dgreports/@dcomm/documents/briefingnote/wcm s_740877.pdf
[2] Brewster A. Why is the underemployment rate important in the coronavirus era? [updated 2020 Apr 15; cited 2020 Apr 26]. Available from https://www.savings.com.au/savingsaccounts/why-is-the-underemployment-rate-important-inthe-coronavirus-era

[3] Samantha C. Hong Kong unemployment rate surges to $4.2 \%$, the highest in nearly a decade. [updated $2020 \mathrm{Apr}$ 21; cited $2020 \mathrm{Apr} 26]$. Available from https://www.human resourcesonline.net/hong-kong-unemployment-ratesurges-to-4-2-the-highest-in-nearly-a-decade

[4] Carville O, Banjo S. US curbs could see 200,000 H-1B workers, many of them Indians, lose legal status by June. [updated 2020 Apr 28; cited 2020 Apr 30]. Available from https://theprint.in/world/us-curbs-could-see-200000h-1b-workers-many-of-them-indians-lose-legal-status-byjune/410687/

[5] Sreevatsan A. Covid-19 lockdown impact: Unemployment rate rises to 23.4\%. [updated $2020 \mathrm{Apr} 7$; cited $2020 \mathrm{Apr}$ 27]. Available from https://www.livemint.com/news/india/ covid-19-lockdown-impact-unemployment-rate-rises-to23-4-11586202041180.html

[6] Bhattacharyya A, Saxena S. 'Historic decline': Canada loses nearly 2 million jobs amid Covid- 19 crisis. [updated 2020 May 9; cited 202012 May] Available from https://www. hindustantimes.com/world-news/canada-loses-nearly-2million-jobs-witnesses-historic-decline-in-employmentamid-covid-19-crisis/story-s0he3LkvZ3tOkG8IuQju6J. html

[7] ILO. Youth: Pathways to Decent Work: Promoting Youth Employment-Tackling the Challenge. [updated 2005 June 15; cited 2019 Apr 30]. Available from https://www.ilo.org/ employment/Whatwedo/Publications/WCMS_104147/lang -en/index.htm

[8] Gowan MA, Riordan CM, Gatewood RD. Test of a Model of Coping with Involuntary Job Loss Following a Company Closing. J of App Psy. 1999;84(1):75-86.

[9] Srivastava P. Key labour laws scrapped in UP for 3 yrs as Yogi govt brings major reform to restart economy. [updated 2020 May 8; cited 2020 May 12]. Available from https://theprint.in/economy/key-labour-laws-scrapped-inup-for-3-yrs-as-yogi-govt-brings-major-reform-to-restarteconomy/416925/

[10] Glyde GP, Davis FG, King CT. Underemployment: Definition and causes. J of Econ Issue. 1977;11(2):245-60.

[11] Feldman DC. The nature, antecedents and consequences of underemployment. J of Mgt. 1996;22(3):385-407.

[12] Bonnal M, Lira C, Addy SN. Underemployment and local employment dynamics: New evidence. The Rev of Reg Stu. 2009;39(3):317-35.

[13] Maddocks HL. Underemployment, unemployment, and mental health. PH.D thesis The School of Graduate and Postdoctoral Studies. Ontario; The University of Western Ontario London; 2012.

[14] Senkrua A. A Review Paper on Visible and Invisible Underemployment. J of Eco. 2018;22(2):83-99.

[15] ILO. Resolution concerning the measurement of underemployment and Inadequate employment situations. [updated 1998 Oct 1; cited 2019 July 13]. Available from http://www. ilo.org/global/statistics-and-databases/standards-and-guide lines/resolutions-adopted-by-international-conferences-oflabour-statisticians/WCMS_087487/lang-en/index.html

[16] Wilkins R. Underemployment in Australia: Evidence from HILDA Survey. [updated 2003 Nov; cited 2019 July 4]. Available from https://melbourneinstitute.unimelb.edu.au/ 
assets/documents/hilda-bibliography/conference-papers-le ctures/2003/Wilkins_Underemployment_in-_Australia.pdf

[17] Maynard DC, Feldman DC. Underemployment: Psychological, Economic and Social Challenges. New York: Springer; 2011.

[18] Gibbons S. The lived experiences of underemployed firstgeneration college graduates. Ph.D dissertation, University of Iowa; Iowa, United States; 2016.

[19] Scurry T, Blenkinsopp J. Under-employment among recent graduates: A review of the literature. Per Rev. 2011;40(5):643-59.

[20] Cunningham J. Genres of underemployment: A dialogical analysis of college Graduate underemployment. Qual Res in Edu. 2016;5(1):1-24.

[21] Livingstone DW. The education - Jobs Exploring the Gap: Underemployment or economic democracy. Toronto: University of Toronto Press; 2004.

[22] Bureau of Labor Statistics, United States Department of Labor. Alternative measures of labor underutilization for states, 2014 annual averages. [updated 2015; cited 2020 April 22]. Available from https://www.bls.gov/lau/stalt.htm

[23] Friedland DS, Price RH. Underemployment: Consequences for the Health and Well-Being of Workers. Amer J of Comm Psy. (2003);32(1/2):33-45.

[24] Wooden M, Dargo R. The changing distribution of working hours in Australia. In: Corbett J, Daly A, Matsushige H, Taylor D, editors. Laggards and Leaders in Labour Market Reform: Comparing Japan and Australia. UK: Routledge Farmer; 2009. p.67.

[25] Pratomo DS. The analysis of underemployment in Indonesia: Determinants and its Implication. Proc - Soc and Beh Sci. 2015;211(25):528-32.

[26] Tasci HM. Recent Trends in Underemployment and Determinants of Underemployment in Turkey. [updated 2005 June 24; cited 2019 April 5]. Available from https://papers. ssrn.com/sol3/papers.cfm?abstract_id $=748045$

[27] Islam AM, Kamarudin SB. Analysing and Forecasting the underemployment trend in Malaysia. Int $\mathrm{J}$ of Soc Sci and Eco Res. 2018;2(1):2018-32.

[28] Hauser PM. The measurement of labour utilization-More Empirical Results. The Mal Eco Rev. 1977;22:10-25.

[29] Sullivan TA. Marginal Workers, Marginal Jobs: the Underutilization of American Workers. Austin, Texas: University of Texas Press; 1978.

[30] Clogg CC, Sullivan TA. Labor force composition and underemployment trends, 1969-1980. Soc Ind Res. 1983;12: 117-52.

[31] Domfe G, Osei RD, Ackah C. Determinants of types of underemployment in the MiDA Intervention Zones of Ghana. Dev Ctry Stu. 2013;3(12):33-47.

[32] Dooley D, Prause J. Social costs of underemployment. New York: Cambridge University Press; 2004.

[33] Maynard DC, Joseph TA, Maynard AM. Underemployment, job attitudes and turnover intentions. J of Org Beh. 2006;27(4):509-36.

[34] Marhaeni AAIN, Yuliarmi NN, Aswitari LP. Underemployment conditions in terms of working hours and income at Badung Regency. Int $\mathbf{J}$ of Sci and Res. 2018;7(7): 923-30.

[35] Brown G, Pintaldi F. A multidimensional approach in the measurement of underemployment. Stats $\mathbf{J}$ of the Uni Nat Eco Comm for Eur. 2006;23(1):43-56.

[36] McGuinness S, Wooden M. Overskilling, job insecurity and career mobility. Ind Rel: A J of Econ and Soc. 2009;48(2):265-86.
[37] Greenwood AM. International Definitions and Prospects of Underemployment Statistics. [updated 1999 Nov 8; cited 2019 July 15]. Available from https://www.ilo.org/wcmsp5/ groups/public/—dgreports/—stat/documents/publication/ wcms_091440.pdf

[38] Wilkins R, Wooden M. Economic approaches to studying underemployment. In: Maynard DC, Feldman DC, editors. Underemployment: Psychological, Economic and Social Challenges. New York: Springer; 2011. p. 13.

[39] Lacmanovic S, Blazevic BS, Tijanic L. The socio-economic costs of underemployment. [updated 2016 June; cited 2019 July 2019]. Available from https://www.researchgate.net/ publication/312135821_The_socio-economic_costs_of_ underemployment

[40] Maynard DC, Parfyonova MN. Perceived over-qualification and withdrawal behaviours: Examining the roles of job attitudes and work values. J of Occup and Org Psy. 2013; 86(3):435-55.

[41] Livingstone DW, Pankhurst KV. Prior concepts and theories of the relationship between workers and jobs. In: DW Livingstone, editor. Education \& jobs: Exploring the gaps. Toronto: University of Toronto Press; 2009. p.11.

[42] McGuiness S. Over education in the labour market. J of Eco Survey. 2006;20(3):387-418.

[43] Verhaest D, Omey E. Discriminating between measures of over education. App Eco. 2006;38(18):2113-20.

[44] Madamba A, De Jong G. Job mismatch among Asians in United States: Ethnic group comparisons. Soc Sci Quat. 1997;78(2):524-42.

[45] Singh BL. Unemployment, Underemployment and Its Effects on Individuals. [updated 2018 Oct; cited 2019 July 4]. Available from https://www.researchgate.net/publica tion/332901108_UNEMPLOYMENT_UNDEREMPLOY MENT_AND_ITS_EFFECTS_ON_INDIVIDUALS

[46] Warr P (1987) Work, unemployment and mental health. Oxford: Oxford University Press; 1987.

[47] Rosenthal L, Carroll SA, Earnshaw VA, Santilli A, Ickovics JR. The Importance of Full Time Work For Urban Adults, Mental And Physical Health. Soc Sci and Med. 2012;75(9):1692-6.

[48] Alberti M. The hidden toll of underemployment. [updated 2011 Nov 9: cited 20194 July]. Available from http://www. remappingdebate.org/article/hidden-toll-underemployment

[49] Dooley D, Prause J, Ham-Rowbottom KA. Underemployment and Depression: Longitudinal Relationships. J of Hlth and Soc Beh. (2000);41(4):421-36.

[50] Bryan ML, Nandi A. Working Hours, Work Identity and Subjective Wellbeing. [updated 2015; cited 202022 April]. Available from https://www.researchgate.net/publication/ 299393708_Working_hours_work_identity_and_subjective _ wellbeing

[51] Cooper C. Can we live with the changing nature of work? J of Mang Psy. 1999;14(7/8):569-72.

[52] Strazdins L, Clements MS, Korda RJ, Broom DH, D'souza RM. Unsociable Work? Nonstandard Work Schedules, Family Relationships, and Children's Well-Being. J of Mrg and Fmly. 2006;68(2):394-410.

[53] Harold-Goldsmith R, Radin N, Eccles JS. Objective and subjective reality: the effect of job loss and financial stress on fathering behaviours. Fly Persp. 1988;22: 309-25.

[54] Pendulla DS, Newman KS. The family and community impacts of underemployment. In: Maynard DC, Feldman DC Underemployment: Psychological, Economic and Social Challenges. New York: Springer; 2011. p. 233. 
[55] Crouter AC, Bumpas MF, Head MR, McHale SM. Implications of overwork and overload for the quality of men's family relationships. J of Mrg and the Fmly. 2001;63(2): 404-16.

[56] Poortman AR. How work affects divorce: the mediating role of financial and time pressures. J of Fmly Iss. 2005; 26(2):168-95.

[57] Pocock B, Buchanan J, Campbell I. Securing quality employment: policy options for casual and part time workers in Australia. [updated 2004 April; cited 2020 Mar 19]. Available from https://trove.nla.gov.au/work/26569577? selectedversion $=$ NBD25846997

[58] Borgen WA, Amundson NE, Harder HG. The expeience of underemployment. J of Emp Cous. 1988;25(4):149-59.

[59] Gray J, Laidlaw H. Part-time employment and communication satisfaction in an Australian retail organisation. Emp Rel. 2002;24(2):211-28.

[60] Deery S, Mahony A. Temporal Flexibility: Management strategies and employee preferences in the retail industry. $\mathrm{J}$ of Ind Rel. 1994;36(3):332-52.

[61] Bashshur MR, Hernandez A and Peiro JM. The impact of underemployment on individual and team Performance. In: Maynard DC, Feldman DC, editors. Underemployment: Psychological, Economic and Social Challenges. New York: Springer; 2011. p.187.
[62] Buris BH. The human effects of underemployment. Soc Prob. 1983;31(1):96-110.

[63] Johnson WR, Morrow PC, Johnson GJ. An evaluation of a perceived overqualification scale across work settings. The J Of Psy. 2002;136(4):425-41.

[64] Cornelißen T. The interaction of job satisfaction, job search, and job changes - an empirical investigation with German panel data. J of Happ Stud. 2009;10(3):367-84.

[65] Li J, Duncan A, Miranti R. Underemployment among mature-age workers in Australia. Eco Rec. 2015;91(295): 438-62.

[66] OECD. Preventing unemployment and underemployment from Becoming Structural. [updated 2014 Sept 10; cited 2019 July 2019]. Available from https://www.oecd.org/ els/emp/OECD-Preventing-unemployment-and-underempl oyment-from-becoming-structural-G20.pdf 